\title{
Features of application of destructors of stubble in the steppe zone
}

\author{
Kovalenko A., Novohyzhnii M., Tymoshenko G., Sergheyeva Yu. \\ Institute of Irrigated Agriculture of NAAS, Naddniprianske, Kherson, 73483, Ukraine \\ e-mail: izz.ua@ukr.net
}

Goal. The increase of soil fertility based on the definition of patterns of changes in soil processes and the formation of the crop for the use of microbial products and by-products of crops in crop rotation, different tillage systems. Methods. Field, laboratory, computational and statistical. Results. It is determined that the degree of destruction of plant residues of winter wheat for 3 months under the influence of decomposers increased in $2.2-2.6$ times in comparison with the control. The most intense decomposition of plant residues of wheat occurred under the influence of preparations Ekostern and Organik-balans (54.5 and $50.2 \%$ respectively); in the control $-21.2 \%$. Application of decomposers increased yield of spring barley on $0,01-0,27 \mathrm{t} / \mathrm{ha}$. For plowing the most effective were the following preparations: Organik-balans, Biodestruktor sterni, and Destruktor tselulozy, which provided an increase of yield on $0.15-0.27 \mathrm{t} / \mathrm{ha}$. For shallow tillage the best was Organik-balans. Conclusions. Application of the microbial preparationsdecomposers in the Southern Steppe is a pretty effective way to improve the biological activity of the soil and increase crop yields. Their effectiveness is vastly improved with sufficient moisture in the soil, whereby the degree of decomposition of plant residues increased by $2.2-2.6$ times in comparison with the control. In drought conditions, the decomposition of plant residues is less influenced by preparations-decomposers, and greater than the control only on 5.9 - 20 absolute percent. The most intensive destruction of plant residues occurs during plowing, when they evenly incorporated throughout the whole depth of the arable soil layer. The use of chisel tillage at the same depth reduces the intensity of mineralization of plant residues on 5.3 - 13.7 percent depending on the culture and moisture conditions of the soil, and use of the shallow subsurface tillage - on $18.7-27.1 \%$.

Key words: plant residues, microbial preparations, soil cultivation, winter wheat, sorghum, yields. DOI: https://doi.org/10.31073/agrovisnyk202002-07

Because of catastrophic decrease in the volumes of production and application of organic fertilizers in Ukraine, each year soil fertility decreases and land degrades, and traditional resources of organic raw material are insufficient for the provision of the non-deficit balance of soil, so, additional reserves of organic matter should be engaged. One of the valuable reserves of the improvement of soil fertility is usage as an organic fertilizer of straw and other plants' residues by their grinding and incorporation into the soil [1, 2]. Soil and plants naturally form the united system. The loss of soil fertility, its degradation deprives plants of the ecological basis for living [3, 4].

Analysis of the last investigations. The revenue of plants' residues into soil has a great value because this is the main source of organic carbon. The revenue of organic carbon improves such indexes of soil fertility as bulk density water permeability, microbial activity of soil [5]. From the beginning of decomposition of plants' residues, the activity and number of microflora steeply increase, and the main share of nitrogen concentrates in the microorganisms $[6,7]$. Thereby, a great part of straw should be returned as a fertilizer in the biological circulation $[8,9]$.

One of the strategic directions of the development of modern agriculture is the usage of biological preparations that will allow renovation of natural resources and obtaining ecologically pure products of crops. The important role among such means belongs to the application of microbial destructors in the technologies of tillage before sowing winter and spring crops. Such microbial preparations are ecologically safe, the microorganisms, which are the constituent elements of biological complexes, are symbiotic, enhance nitrogen nutrition of plants and increase the amounts of mobile forms of phosphorus and potassium, activate mineralization of hardly available phosphates and other soil minerals [10, 11].

The goal of the study - the increase of soil fertility on the basis of determination of the regularities of changes in the soil processes and formation of yield at the application of microbial preparations and byproducts of crops in crop rotation at different tillage systems.

Methods of the study. At the experimental field of the Institute of Irrigated Agriculture of NAAS the study was conducted within the crop rotation: fallow - winter rape - winter wheat - sorghum - spring barley - sunflower.

The soil of the experimental field is dark-chestnut middle-loamy soil with the humus content in the arable layer of $2.2 \%$. The field water capacity of the meter layer is $22.4 \%$, wilting point $-9.5 \%$. Groundwater is deeper than $10 \mathrm{~m}$.

The sowing area of the first degree is $500 \mathrm{~m}^{2}$ : accountable area $-100 \mathrm{~m}^{2}$; the second degree plot area $-50 \mathrm{~m}^{2}$. The plots were placed systematically. The study was conducted in three replications.

The study was performed in the stationary double-factored experiment where the following microbial 
preparations were studied: the control; Biodestruktor sterni; Ecostern; Organic-balance; Bionorm; Destruktor tseliulozy at three tillage systems: plowing; deep plowless tillage (chisel); shallow plowless tillage (disking).

The results of the study. During the conduction of the study in the decomposition of plants' residues of crops, we used the residues of the winter wheat of 2016 yielding year, and the residues of the sorghum of 2017 yielding year. In the reserches of 2016, the biomass of the winter wheat stalks at the plowing under fallow was $5.24 \mathrm{t} / \mathrm{ha}$, at the chisel tillage $-4.84 \mathrm{t} / \mathrm{ha}$, and at the shallow tillage $-4.66 \mathrm{t} / \mathrm{ha}$, and it was left on the field as stubble and grinded straw. In the researches of 2017, the biomass of the sorghum stems at the background of plowing was $4.10 \mathrm{t} / \mathrm{ha}$, at the deep plowless tillage $-3.77 \mathrm{t} / \mathrm{ha}$, and at the shallow plowless tillage $-3.42 \mathrm{t} / \mathrm{ha}$.

By the results of our earlier conducted researches, the $\mathrm{N}: \mathrm{C}$ ratio in the straw of winter wheat was 1:73 with the content of nitrogen $0.51 \%$ and the content of carbon $37.48 \%$. The content of phosphorus in the straw was $0.25 \%$. The total gross content of nitrogen in the straw that left after the harvesting of winter wheat in the variant with plowing was $26.7 \mathrm{~kg} / \mathrm{ha}$, at the chisel tillage at the same depth $-24.7 \mathrm{~kg} / \mathrm{ha}$, and at the shallow plowless tillage $-23.8 \mathrm{~kg} / \mathrm{ha}$. The content of carbon in the straw was 1964, 1814 and 1747 $\mathrm{kg} / \mathrm{ha}$, respectively (Table 1 ).

1. Biomass of winter wheat and its chemical composition in dependence on the tillage (2016 autumn)

\begin{tabular}{|c|c|c|c|}
\hline \multirow{2}{*}{ Tillage } & \multirow{2}{*}{ Mass of the straw, t/ha } & \multicolumn{2}{|c|}{ Accumulation, $\mathrm{kg} / \mathrm{ha}$} \\
\cline { 3 - 4 } & & nitrogen & carbon \\
\cline { 3 - 4 } & & 26.7 & 1964 \\
\hline \multirow{2}{*}{ Plowing } & 5.24 & 24.7 & 1814 \\
\hline Deep plowless tillage & 4.84 & 23.8 & 1747 \\
\hline Shallow plowless tillage & 4.66 & & \\
\hline
\end{tabular}

The herbage of sorghum contained $0.68 \%$ of nitrogen, $0.36 \%$ of phosphorus, and $1.12 \%$ of potassium. The total gross content of nitrogen in the herbage that left after the harvesting of sorghum on the variant with plowing was $27.9 \mathrm{~kg} / \mathrm{ha}$, at the chisel tillage at the same depth $-25.6 \mathrm{~kg} / \mathrm{ha}$, and at the shallow plowless tillage $-23.3 \mathrm{~kg} / \mathrm{ha}$. The accumulation of phosphorus was $12.3-14.8 \mathrm{~kg} / \mathrm{ha}$, of potassium $-38.3-45.9 \mathrm{~kg} / \mathrm{ha}$ (Table 2).

2. Biomass of sorghum and its chemical composition in dependence on the tillage (2017 autumn)

\begin{tabular}{|c|c|c|c|c|}
\hline \multirow{2}{*}{ Tillage } & \multirow{2}{*}{ The herbage mass, $\mathrm{t} / \mathrm{ha}$} & \multicolumn{3}{|c|}{ Accumulation, $\mathrm{kg} / \mathrm{ha}$} \\
\cline { 3 - 5 } & & nitrogen & phosphorus & potassium \\
\cline { 3 - 5 } & & 27.9 & 14.8 & 45.9 \\
\hline Plowing & 4.10 & 25.6 & 13.6 & 42.2 \\
\hline Deep plowless tillage & 3.77 & 23.3 & 12.3 & 38.3 \\
\hline Shallow plowless tillage & 3.42 & & & \\
\hline
\end{tabular}

The post-harversting period of 2016 was characterized by high air temperatures. So, average daily temperature in July was $24.4^{\circ} \mathrm{C}$, in August $-24.7^{\circ} \mathrm{C}$, in September $-18.0{ }^{\circ} \mathrm{C}$, and only in October it significantly decreased to $8.4^{\circ} \mathrm{C}$ that created favorable conditions for microorganisms - biological agents of the destructors' preparations. During July, August and September the amount of precipitation was low 46.3, 26.7 and $33.2 \mathrm{~mm}$, and this resulted in the periodical drying of the upper layer of the soil. After the harvesting of winter wheat the storage of productive moisture in the $10 \mathrm{~cm}$ layer of the soil was $4.0 \mathrm{~mm}$. Significant precipitation was just in October $-74.4 \mathrm{~mm}$. Weather conditions and soil humidification conditions at the first stages were not very favorable for the efficient activity of the preparations of stubble destructors. But at the use of them the degree of the crops' residues destruction increased 2.2-2.6 times in comparison to the variant without them (Table 3). 
3. The degree of winter wheat straw destruction after 90 days from the treatment with the microbial destructors, \% (2016 — autumn)

\begin{tabular}{|c|c|c|c|c|}
\hline \multirow{2}{*}{ Preparation-destructor } & \multirow{2}{*}{ Plowing } & \multicolumn{2}{|c|}{ Plowless tillage } & \multirow{2}{*}{$\begin{array}{c}\text { Average by the } \\
\text { preparation }\end{array}$} \\
\hline & & deep & shallow & \\
\hline The control & 23.0 & 21.9 & 18.7 & 21.2 \\
\hline Biodestruktor sterni & 55.8 & 48.1 & 40.8 & 48.2 \\
\hline Ecostern & 63.6 & 53.9 & 45.9 & 54.5 \\
\hline Organic-balance & 59.7 & 49.4 & 41.6 & 50.2 \\
\hline Bionorm & 56.1 & 47.6 & 40.0 & 47.9 \\
\hline Destruktor tseliulozy & 52.2 & 46.5 & 39.0 & 45.9 \\
\hline Average by the tillage & 51.7 & 44.6 & 37.7 & \\
\hline
\end{tabular}

The highest increase in the degree of the straw decomposition after 90 days from the application was provided by the preparation Ecostern $-54.5 \%$ that is by $33.3 \%$ better than at the control variant. Very efficient activity was observed at the use of Organic-balance when $50.2 \%$ of the winter wheat straw was decomposed. The slowest decomposition of the straw in the conduitions of 2016 was provided by the preparations Destruktor tseliulozy and Bionorm that caused the destruction by 45.9 and $47.9 \%$, respectively.

The process of the straw destruction was significantly affected by the way and depth of tillage that is connected with the depth of the crops' residues incorporation and different conditions of the soil humidification in the layer of the straw allocation. On the control variant without application of the destructors, the change of plowing on plowless tillage at the same depth decreased the degree of decomposition by 1.1 relative percent, and switch to the shallow plowless tillage - by $4.3 \%$. In average by the factor of tillage, plowless tillage decreased the degree of destruction by $7.1 \%$, and switch to the shallow tillage - by $14.0 \%$ in comparison to plowing.

The beginning of the autumn of 2017 on the territory of Kherson region was distinguished by very difficult agrometeorological conditions. More than 100 days severe air and soil drought was observed. At the moment of sorghum harvesting there was no productive moisture in the arable layer of the soil - the moisture was below the wilting point. At these conditions, decomposition of the sorghum stalks was very slow. If in the more humid conditions of the autumn of 2016 in the control variant the straw in 90 days was decomposed by 18.7-23.0\% depending on the tillage, in 2017 - just by $16.1-20.2 \%$. Herewith, the application of preparations-destructors increased the degree of the straw decomposition in 2017 just by $5.9-20.0 \%$ (Table 4).

4. The degree of destruction of the sorghum herbage after 90 days from the treatment with the microbial destructors, \% (2017 - autumn)

\begin{tabular}{|l|c|c|c|c|}
\hline \multirow{2}{*}{ Preparation-destructor } & \multirow{2}{*}{ Plowing } & \multicolumn{2}{c|}{ Plowless tillage } & \multirow{2}{*}{$\begin{array}{c}\text { Average by the } \\
\text { preparation }\end{array}$} \\
\cline { 3 - 4 } & & deep & shallow & \\
\hline The control & 20,2 & 19,1 & 16,1 & 18,5 \\
\hline Biodestruktor sterni & 21,7 & 20,8 & 16,4 & 19,6 \\
\hline Ecostern & 22,3 & 21,7 & 19,6 & 21,2 \\
\hline Organic-balance & 23,7 & 22,9 & 20,1 & 22,2 \\
\hline Bionorm & 22,9 & 22,1 & 19,1 & 21,4 \\
\hline Destruktor tseliulozy & 24,1 & 21,1 & 18,6 & 21,3 \\
\hline Average by the tillage & 22,5 & 21,3 & 18,3 & \\
\hline
\end{tabular}

In these conditions, the best performance was provided by the preparation Organic-balance. The increase in the sorghum stalks decomposition with the application of this preparation was in average 3.7 
relative percents. There was almost no effect on the tempo of the stalks mineralization under the use of Biodestruktor sterni. The preparation Organic-balance was the best almost at all the variants of tillage. However, we should mention, that at the plowing the highest degree of destruction was observed at the application of Destruktor tseliulozy.

The depth of the sorghum residues incorporation that depended on the way and depth of the tillage also had its effect on the tempo of mineralization. The maximum it was during the period of 90 days at plowing $-22.5 \%$, that is much higher than at the shallow plowless tillage.

Under the influence of the microbial preparations-destructors, which were used for the treatment of the plants' residues, the process of the decomposition cahnged biological activity of the soil in the crops of both sorghum after winter wheat and spring barley after sorghum. So, transformation of the organic matter of the crops' residues of winter wheat under the influence of the microbial preparations caused an increase in the quantity of microorganisms that take part in the processes of transformation of nitrogen compounds. The quantity of ammonifying microorganisms in the arable layer of the soil at the beginning of sorghum vegetation increased at the background of plowing by $0.11-3.65 \mathrm{million} / \mathrm{g}$ in comparison to the untreated variant. The highest number of the microorganisms of this group was at the application of the preparation Organic-balance - 21.96 million/g.

At the deep plowless tillage, the highest quantity of ammonifyiers was at the application of the preparation Destruktor tseliulozy that surpassed other variants by $0.65-3.90 \mathrm{million} / \mathrm{g}$. In the variant with shallow plowless tillage, the quantity of ammonifying microorganisms was the highest at the application of the preparation Bionorm - 21.54 million/g.

It should be mentioned that the number of ammonifying microorganisms in the arable layer of soil is strongly connected with the degree of winter wheat straw destruction, that is testified by the correlation $-r$ $=0.77$ (Fig.).

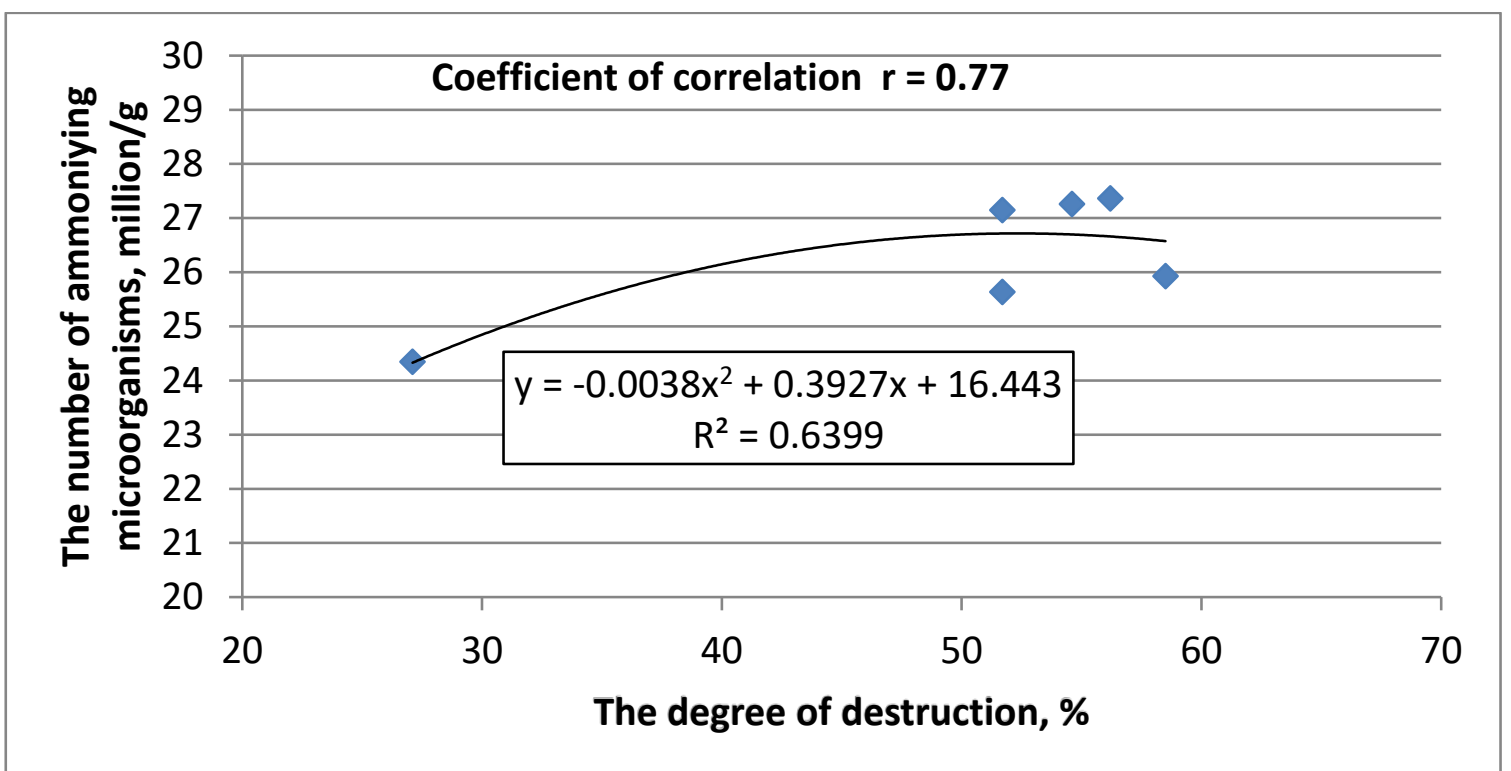

Correlation between the degree of wheat straw destruction and the number of ammonifying microorganisms in the soil layer of $0-30 \mathrm{~cm}$ under the sorghum crops at the stage of panicle formation

The number of ammonifying microorganisms in the soil layer of $0-30 \mathrm{~cm}$ in the period of spring barley tillering in the variants with application of the preparations-destructors at the background of plowing increased by $4.8-23.5 \%$. The maximum quantity of microorganisms of this group was at the application of the preparation Ecostern.

In the conditions of chisel tillage, the number of ammonifying microorganisms in the soil was by 3.6$44.2 \%$ higher than at plowing. At this type of the tillage, the number of ammonifying microorganisms at the background of application of the preparations Ecostern and Bionorm was by 2.87-4.87 million/g higher than on the control, and close to the other preparations.

At the background of shallow plowless tillage, only in the variants with application of the preparations Bionorm and Destruktor tseliulozy the number of ammonifying microorganisms significantly surpassed the control variant by $3.5-7.7 \%$.

The number of nitrifying microorganisms also changed under the influence of the microbial preparations and ways of the tillage. But the differences between the variants were slightly less than by ammonifying microorganisms.

The process of change in microbiological activity of the soil affetced on its fertile regime. So, the number of nitrates in the arable layer of the soil at the beginning of sorghum vegetation was higher than at the 
treatment of straw by the preparation Destruktor tseliulozy $-57.0 \mathrm{mg} / \mathrm{kg}$, or by $20.4 \mathrm{mg} / \mathrm{kg}$ more than on the control. Their content was by $8.6-13.4 \mathrm{mg} / \mathrm{kg}$ lower on the variants with application of the other preparations. At the stage of flowering of sorghum, there was observed an increased content of nitrates in the soil, the advantage had the preparation Biodestruktor sterni $-74.4 \mathrm{mg} / \mathrm{kg}$. Further, until the end of the plants' vegetation, the significant advantage had the variant with application of the preparation Destruktor tseliulozy $-32.1 \mathrm{mg} / \mathrm{kg}$ of the soil.

At the beginning of vegetation of spring barley, the content of nitrates in the soil layer of $0-30 \mathrm{~cm}$ at the background of plowing in the condition of application of the preparations-destructors was by $1.8-9.6 \mathrm{mg} / \mathrm{kg}$ higher than on the control. The maximum was in the variants with application of the preparations Ecostern and Destruktor tseliulozy -26.2 and $27.0 \mathrm{mg} / \mathrm{kg}$, respectively.

In the conditions of deep chisel tillage, the content of nitrates was lower than at plowing. No preparation had an advantage. Application of the preparations Biodestruktor sterni, Ecostern and Organic-balance on the background of shallow plowless tillage was favorable for the increase in the content of nitrates by 2.4$6.5 \mathrm{mg} / \mathrm{kg}$.

At the end of spring barley vegetation due to the less nitrogen consumption in the stage of grain ripening, the content of nitrates in the soil increased. In this period at the background of deep tillage, the maximum content of nitrates was at application of the preparations Ecostern and Organic-balance 34.8 and 30.5 $\mathrm{mg} / \mathrm{kg}$ at the background of plowing, and 26.7 and $24.1 \mathrm{mg} / \mathrm{kg}$ at the background of chisel loosening that is by $41.2-73.3 \%$ better than on the control.

In the variant with shallow plowless tillage all the preparations-destructors, excluding Biodestruktor sterni, led to significant increase in the nitrates content in the arable layer of the soil.

Nitrification capacity of the soil was marginally affected by the microbial preparations, these changes were less evident.

Changes in biological activity and fertile regime of the soil in the process of the plants' residues decomposition under the influence of the microbial preparations at different tillage affected the yiled of the further crops in the crop rotation (Tables 5, 6).

At the background of plowing, the highest yield of sorghum was obtained at the application of the preparation Organic-balance $4.76 \mathrm{t} / \mathrm{ha}$ and Ecostern $-4.38 \mathrm{t} / \mathrm{ha}$.

A switch to the deep plowless tillage diminished the effect of the destructors and the difference between the variants was $0.67-0.35$ t/ha. At this tillage system the advantage is in the use of the preparations Organic-balance with the yield of $4.36 \mathrm{t} / \mathrm{ha}$ and Ecostern $-4.01 \mathrm{t} / \mathrm{ha}$.

\section{Sorghum grsain yield in dependence on the tillage and the microbial destructors, tha (2017)}

\begin{tabular}{|l|c|c|c|c|}
\hline \multirow{2}{*}{\begin{tabular}{c}
\multirow{2}{*}{$\begin{array}{c}\text { The preparation } \\
\text { (factor B) }\end{array}$} \\
\cline { 2 - 5 }
\end{tabular}} & \multicolumn{3}{|c|}{ plowing tillage (factor A) } & $\begin{array}{c}\text { Average by the } \\
\text { factor B }\end{array}$ \\
\cline { 2 - 5 } & 3.32 & 3.01 & 2.90 & 3.08 \\
\hline The control & 4.13 & 3.83 & 3.27 & 3.74 \\
\hline Biodestruktor sterni & 4.38 & 4.01 & 3.78 & 4.06 \\
\hline Ecostern & 4.76 & 4.36 & 3.81 & 4.31 \\
\hline Organic-balance & 3.96 & 3.69 & 3.29 & 3.65 \\
\hline Bionorm & 4.03 & 3.71 & 3.44 & 3.73 \\
\hline Destruktor tseliulozy & 4.10 & 3.77 & 3.42 & \\
\hline Average be the factor A & & \multicolumn{2}{|c|}{ plowless tillage } & \\
\hline
\end{tabular}

LSD $_{05}$ t/ha partial differences: factor $A-0.23$; factor $B-0.20$

main effects: factor $A-0,09$; factor $B-0,11$

The shallow plowless tillage resulted in almost equal yield of sorghum under the use of the preparations Ecostern and Organic-balance - 3.78-3.81 t/ha. The treatment of the straw with the preparations Bionorm, 
Destruktor tseliulozy and Biodestruktor sterni led to formation of slightly lower yield, but it was better than on the control.

At the background of plowing the highest yield of barley grain was obtained at the application of the preparations Organic-balance, Biodestruktor sterni and Destruktor tseliulozy 2.25-2.37 t/ha. In comparison with the other preparations, treatment of the straw with the preparations Bionorm and Ecostern was favorable for the less increase in the barley yield - by $0.06-0.11 \mathrm{t} / \mathrm{ha}$.

A switch to the deep plowless tillage diminished the effect of the destructors of stubble, and the difference between the variants was $0.01-0.18 \mathrm{t} / \mathrm{ha}$. At this system of tillage the advantage belonged to the preparation Destruktor tseliulozy with the yield of $2.23 \mathrm{t} / \mathrm{ha}$.

6. Yield of spring barley in the conditions of application of the microbial destructors at the background of different ways of tillage, $t /$ ha (2018)

\begin{tabular}{|c|c|c|c|}
\hline \multirow{2}{*}{$\begin{array}{c}\text { Variant of the } \\
\text { preparation, } \\
\text { (factor B) }\end{array}$} & Plowing & Chisel & Disking \\
\cline { 2 - 4 } & 2.10 & 2.05 & 1.87 \\
\hline The control & 2.31 & 2.06 & 1.86 \\
\hline Biodestruktor sterni & 2.16 & 2.13 & 2.10 \\
\hline Ecostern & 2.25 & 2.17 & 2.07 \\
\hline Organic-balance & 2.21 & 2.10 & 1.99 \\
\hline Bionorm & 2.37 & 2.23 & 1.89 \\
\hline Destruktor tseliulozy & 2.23 & 2.12 & 1.96 \\
\hline Average by the tillage & & & \multicolumn{3}{|c|}{ The tillage, (factor A) } \\
\hline
\end{tabular}

LSD 05 partial differences: A - 0.10; B - 0.14 main efects: $\quad A-0.06 ; B-0.06$

In the condition of shallow plowless tillage, the effect of the microbial preparations-destructors was the least in comparison with the deep tillage. The yield of spring barley grain in the variants with application of the preparations-destructors Ecostern and Organic-balance was almost equal $-2.07-2.10 \mathrm{t} / \mathrm{ha}$, that is by $0.21-0.23 \mathrm{t} / \mathrm{ha}$ higher than the control.

\section{Conclusions}

Application of microbial preparations-destructors in the conditions of Southern Steppe is an efficient way of the improvement of biological activity of soil and the increase of crops yield. Their efficiency is significantly increased under conditions of sufficient moisture of the soil, resulting in the increase of the degree of destruction of plant residues 2.2-2.6 times in comparison to the control. In the conditions of drought, decomposition of plant residues under the influence of preparations-destructors is less intensive and surpasses the control by only 5.9-20 absolute percents. The most intensive destruction of plant residues occurs in the conditions of plowing, when they are evenly incorporated throughout the whole depth of the arable soil layer. The use of chisel soil loosening at the same depth reduces the intensity of mineralization of plant residues by 5.3-13.7\% depending on the crop and conditions of soil humidification, and shallow subsurface tillage - by $18.7-27.1 \%$.

\section{References}

Centylo, V. M., \& Sendeczkyj, L.V. (2014). Biologichna efektyvnist vykorystannya biodestruktoriv [Biological effectiveness of using biodegraders]. Bulletin of Zhytomyr National Agro-Ecological University. Agroecology, 2 (42), 1, 93-99. [In Ukrainian]

2. Govorov, O. (2014). Shho robyty z solomoyu? [What to do with straw?]. Offer. Univest Media LLC, 5, 118. [In Ukrainian]

3. Maklyuk, O., \& Najdonova, O. (2014). Biologichno aktyvni grunty: yak yix sformuvaty. Offer. Univest Media LLC, 10, 68. [In Ukrainian]

4. Boloxovska, V., \& Nagorna, O. (2012). Biodestruktory na storozhi zdorov'ya gruntu [Biologically active soils: how to form them]. Offer. Univest Media LLC, 5, 60. [In Ukrainian] 
5. Tarkalson, D., Braun, B., \& Kok, G. (2015). Posledstvyya uborky solomy s polya pry vozdelyvanyy pshenyczy y yachmenya [The consequences of harvesting straw from the field when cultivating wheat and barley]. Agronomist, 2, 192. [In Russian]

6. Carter, D., \& Findlater, P. (1989). Erosion potential of phomopsisresistant lupin stubbles. West Australian J. of Agrikulture, 30, 11-14.

7. Fowber, D., \& Brydon, J. (1989). No-till winter wheat production on Canadian prairies: placement of urea and ammonium nitrate fertilizers. Agronomy J., 81, 3, 518-524.

8. Skrylnyk, Ye. (2013). Efektyvnist vykorystannya pislyazhnyvnyx reshtok [Effective use of post-harvest residues]. Offer. Univest Media LLC, 7, 64. [In Ukrainian]

9. Nagorna, O. I. (2013). Keruvaty rodyuchistyu mozhna. Posibnyk ukrayinskogo khliboroba [You can manage fertility. Handbook of the Ukrainian farmer]. (Vol. 1, p. 11). ACADEMPRESS LLC. [In Ukrainian]

10. Bogovin, A. V. (2009). Biogeocenotychna rol vzayemovidnosynzhyvyx organizmiv u stanovlenni ta funkcionuvanni ekologichnyx system [Biogeocenotic role of relationships of living organisms in the formation and functioning of ecological systems]. Ecology and noosphere. Dnipropetrovsk, 1-2, 20, 102117. [In Ukrainian]

11. Volkogon, V. V., Nadkrenychna, O. V., Kovalevska, T. M. et al. (2006). Mikrobni preparaty u zemlerobstvi. Teoriya i praktyka [Microbial preparations in agriculture. Theory and Practice]. Kyiv: Agrarian Science. [In Ukrainian] 